Copyright ( $) 2016$ SCAD Independent

All Rights Reserved

Printed in the Indonesia
Jurnal Ilmiah Peuradeun Vol. 4, No. 2, May 2016

\title{
THE NATIVE CULTURES ON STUDENT DISCIPLINE IN SCHOOL, NIGERIA
}

\section{Edewor Ogwu}

Department of Educational Administration and Policy Studies Faculty of Education, Delta State University Abraka, Nigeria.

Email: edewog@yahoo.com

Received: Nov 18, 2015

Accepted: Jan 30, 2016

Published: May 28, 2016

Article Url: https://journal.scadindependent.org/index.php/jipeuradeun/article/view/97

\begin{abstract}
Students discipline problem is developing into an epidemic in Nigerian schools. Every culture has its own values and norms, and these are communicated to its young generation through disciplinary strategies; and being culturally conceptualized and negotiated, these strategies and the languages therein, can only be understood by the members of the identifiable cultural group. The study evaluates some relevant information on teachers' routine experiences and their views on the effectiveness the enforcement of order, control and disciplinary actions in secondary schools and how school disciplines are influenced by the cultural background of the Staff and students. This study explores teachers' views on the common approaches and school disciplinary models in Nigeria. The paper suggests that the current educational administration and policies erodes the powers of the secondary Staff to such degree that teachers are disempowered hence, indiscipline among students continues to gather momentum causing poor academic performances.
\end{abstract}

Keywords: Native, Culture, Discipline, Students, Schools, Nigeria 


\section{A. Introduction}

Culture is a complex concept which includes knowledge, beliefs, arts, morals, customs and any other capabilities acquired by man as a member of the society. It is the sum total of a given society's way of life molded and shaped by prevailing circumstances and environment (Brown, 1990). This implies that culture is not static both dynamic and it responds to external influences, and there by bringing about changes and curriculum development in schools.

A school or an environment does not exist in vacuum, and children are not born with any culture but are born into a culture; people have long been aware of cultural differences among societies, and the ways of life and interaction of diverse social groups. Amongst the features of cultural interactions are languages, social thought, spirituality, mode of dressing etc. This implies that cultural aspects of human behavior are not biological based or conditioned but are acquired solely through learning and environmental interactions. Also, cultures are equally developed according to priorities and values; hence, children disciplines are integral aspect of Nigeria's native cultures as disciplines seem to emanate from home (Day - Vines and Day - Harrison, 2005).

On the other hand, the word discipline signifies the presence of some form of orderliness where there is the existence of an enforcer. Discipline is part of socialization; every culture has its own approaches, informed by norms and beliefs crafted by the people of that culture. The concept of discipline in schools has been contentious issue in recent years. The term discipline means and implies so many things and can only be clearly understood within the context in which it is used. It contains positive and negative values in the characterization of behavior and it connotes "good" as well as "bad". It means a mode of life in accordance with rules many definitions that have been put forward by different writers.

The issue of culture and discipline in Nigerian schools has never been of much concern and threat to the educational system. In the past few years, there has been rising incidents of serious misconduct by students (Oroka, 1994). There are alleged cases of teachers being threatened or attacked by students in the secondary schools. In some cases the attacks have been violent. Similarly, punishments have been imposed and some of which have 
been administered harshly with little or no consideration for the age, sex or cultural background of the students. In the midst of these problems, there is a growing debate over the declining standard of education as caused by students' unrests; and the routine blaming of teachers for being unproductive. Parents have also been accused of abdicating their responsibility of rearing responsible children (Nwideeduh, 2003).

Some of the native cultures are being altered and modified by Christianity which attribute the origin of order, discipline and control to the Garden of Eden, when Adam and Eve disobeyed God's order, and were punished (Genesis 3: 14-19). Thereafter, discipline became an integral part of human growth and development, hence, the proverb "spare the rod and spoil the child". The Christian Bible construes the 'sparing of the rod' as an open act of child neglect and hate. Parents therefore are expected to correct or discipline their children. This means that discipline deals with good behavior and every society wants its children to get proper socialization; hence the saying, of the Yorubas (an ethnic group in Nigeria), "lore lo ojwa losa le metsi" which means "a rod is easily bent while still tender". However, gone are the days when a black African child showed respect and honors to elderly people regardless of whether they are related or not (Ovwata, 2000).

These cultural influences are usually infiltrated by philosophies and practices of other cultures; hence the government of Nigeria acknowledges that:

“Nigeria's social structure rests upon a long history and culture, and a set of traditions governing the behavior and obligations of people towards each other and the community as a whole. It is important that this culture, built over a long period of time, is strong enough to absorb and filter the influx of new ideas and patterns of behavior without losing its coherence" (Peretomode, 1993).

The neglecting of the importance of native cultures by schools is causing frictions and affecting the enforcement of disciplines. This paper restricted itself to government regulations and explored teachers' views on whether or not such regulations support cultural norms of child rearing practices. Apart from imparting knowledge and facilitating student learning, teachers are expected to maintain security and order in classrooms (Bogdan, 2004). Thus, the issue of 
students' conduct is a factor in their job satisfaction and they can resign from the profession if students' misbehavior is unbearable (Mclntyre and Silva 1992). Students' misconduct is not only a nuisance to teachers; it affects the norms of the society as well.

Peretomode (1993) defined discipline as the process whereby one comes to regulate his own behavior to fit in with large purpose or norms of the society. He believes that one of the biggest problems confronting Nigeria as a developing nation is the dwindling standards of discipline. This view was supported by Nakpodia (2003) that suggests that discipline is a system of guiding the individual to make reasonable and responsible decisions. What emerges from these view points is that discipline in the school may be seen as the exhibition of the spirit of right conduct by students and teachers in conformity with societal norms and school regulations which help in the smooth running of the school. Hence, Nakpodia (2006) also maintained that discipline in school is used to refer to the maintenance of general conditions or order without which nothing can be effectively achieved.

In its most general sense, discipline refers to systematic instruction given to members of a group such as students in a school. To discipline means to instruct a person to follow a particular code of conduct. Usually, the phrase "to discipline" carries a negative connotation. This is because enforcement of order that is ensuring instructions are carried out - is often regulated through punishment. Consequently, in the field of child development, discipline refers to methods of modeling character and of teaching self control and acceptable behavior. To be disciplined is then, subject to content, either a virtue, which may be referred to as disciplinary procedure or a euphemism for punishment, which may also be referred to as disciplinary procedure (Reyes, 2006).

On the other hand, school discipline refers to regulation of children and the maintenance of order ("rules") in schools. These rules may, for example, define the expected standards of clothing, timekeeping, social behavior and work ethic. The term may also be applied to the punishment that is the consequence of transgression of the code of behavior. For this reason the term school discipline sometimes means the administration of punishment, rather than behaving within the school rules. 
According to (Zindi, 1995) violence and misbehavior exist in schools. This lack of discipline, which interferes with the teaching and learning process, manifests itself in various ways including bullying, criminality, vandalism, alcohol and drugs abuse, truancy, inability or unwillingness to do homework (Douglas \& Strauss, 2007).

The native cultures emphasizes on respect for elders, total obedience to rules and adequate compliance to societal norms. These attributes of native culture is shared; that is, it is practiced by a whole group of people from generation to generation (Fowers, 2008). Culture is maintained or modified through informal education and expected to be integral aspect of the school curriculum development. This is because where educational institutions discharge their duties well; they influence the total life of the society (Banda, 2004). Where the societal norms are contrary to the school sets of rules, there is possibility of cultural shocks to the students (Reyes, 2006; Day-Vines and Day-Harrison, 2005).

\section{B. Method and Materials}

This paper is based on current developments in the educational sector of Nigeria's political institutions. Materials are documentary scholarly collections from various sources. No hypothesis was formulated and analyzed. The richness of the paper is enhanced through the presentation of in-depth arguments on the subject matter of discipline schools.

\section{Discussion}

The education Act 1967 has been criticized for violating the rights of school heads. Imaguezor (1997) finds that $65 \%$ of the population is not in favors of the schools' disciplinary process which rest powers on the Minister of Education, giving very little powers to the individual school heads. It also noted that the bureaucracy involved in the suspension and exclusion of indiscipline students takes too long for desired outcome to be achieved, in essence, for a student to actually commence a suspension, the head teacher has to send the recommendation for the approval of the relevant education authority taking too long for the punishment to be 
effected. This time gap allows the student to cause more havoc and possibly influence other students negatively.

Nigerian teachers insinuate that the reason for the exponential growth of cases of students' misconduct is that school regulations are not founded in the cultural strategies for disciplining children. It is claimed that children discipline is an integral part of child socialization hence, is not a lonesome work involving the entire society and not just the schools. However, teachers in Nigeria regularly lament that they are not adequately protected and authorized to be involved in the disciplinary process in that they are relatively helpless especially when they encounter discipline challenges in classrooms where the school head is not always nearby. Although only the school head is allowed to administer corporal punishment, most teachers ignore this regulation. However, teachers believe that the manner in which parents and the general public treat them is influenced by school discipline regulations. Teachers complain that they are rarely respected by parents and if it happens that they punish learners, their parents would come to reprimand them even in the presence of the students. One teacher said: "Students misbehave with the knowledge that they are not supposed to be beaten and also knowing that if it happens that the teacher beats them, their parents are going to follow that teacher or even sue him/her" (see Kodilinye, 1990; Peretomode, 1993 and Oroka, 1994).

Teachers find the school discipline regulations practiced in Nigerian schools problematic (Nwideeduh, 2003) in that classroom control has become somehow cumbersome. This is because students are prone to misconduct knowing that the teachers are not allowed to administer corporal punishment. Suspension and expulsion regulations cause some ambivalence in the school administration. When it comes to making decisions about a problem learner, the school head has to think carefully as not to cause him some embarrassment which often follow the revocation of school's decisions by the education authorities.

Corruption culture in the society plays vital parts of school discipline processes. Influential parents are capable of reversing the schools decision to 
exclude their children by 'greasing the palms' of corrupt officials of the education authorities. The lengthy and cumbersome disciplinary procedures make students to believe that the school heads have no authority to enforce disciplines making it possible for consistent misbehaviors.

Students' misbehaviors impact negatively on teachers performances. There are at least two effects of lack of discipline on teachers' jobs. Firstly, teachers feel insecure (Matsimoto, 2000 and Kayode, 1984); Secondly, too much time is spent trying to effect the discipline procedures and less time is spent on teaching.

The Ministry of Education perceives the school discipline regulations as an endeavor to promote and maintain order and safety in schools, teachers' point of view differs. According to these teachers, the corporal punishment, suspension and expulsion regulations are a scheme which strips off their rightful authority over students. They feel disempowered. They claim that these regulations contravene the cultural practices of child upbringing where every adult in a society was regarded as a parent and had the right to discipline any child as s/he sees it fit. Similarly, teachers regard themselves as parents, aunts and uncles of the student community as in the doctrine of in-loco-parentis. Their assertion is that if the Ministry of Education wanted to inculcate the Nigerian cultural philosophy into school, the school regulations would not be discriminating against positions. Each and every teacher as a parent, in-loco-parentis, would have been given the privilege of molding students' characters into that of desirable citizenry. This, they believe, would be a successful approach to students' discipline.

Because the school head, who is the only person designated to punish students cannot simultaneously be available at all times in all classrooms, teachers experience indiscipline at an alarming rate. They feel powerless. They assert that it is difficult to be a teacher these days. They complain that the Ministry of Education is not giving them enough support especially in cases of suspension and expulsion. Time and again, the school heads are ambivalent when it comes to making such decisions. This lack of action brings chaos in the 
schools. When the Permanent Secretary overrules the school's recommendation, the students' community mumbles and a seed of distrust is sown in the 'school culture'. The school head's limited power over expelling students is regarded by teachers as the violation of his/her rights.

\section{Conclusion.}

Students discipline problem is developing into an epidemic in Nigerian schools. Every culture has its own values and norms, and these are communicated to its young generation through disciplinary strategies; and being culturally conceptualized and negotiated, these strategies and the languages therein, can only be understood by the members of the identifiable cultural group (Mbiti, 1988)". By ignoring the impact of native culture on students' discipline policies is tantamount to promoting cosmetic, astral, disciplinary approaches; thus alienating the child from his/her own culture.

It is for this reason that the Nigerian government must not ignore the encompassment of native norms and native cultural discipline into the schools' curriculum and practice. The lack of adequate discipline in schools would transmit into societal chaos and destruction. Little wonder, Oroka (1994: 101) aptly observed that "Whatever values that are taught in schools could be negated by the larger society if the larger society has conflicting values". A discipline mind is an asset of any society, and the school is part of the process for training the youth in other to produce a balanced and disciplined citizen. The phrase that "the school is a silent teacher of morals" should be taken seriously.

\section{Bibliography}

Banda A (2004) Parents order whipping of Masunga SSS students. Mmegi Newsletter. Gaborone 19 May.

Bogdan RC, Biklen SK (1992) Qualitative research for education: An introduction to Theory and Methods. Boston: Allyn and Bacon. 
Brown BB (1990) Peer Groups and Peer Cultures. In S. Feldman \& G. Elliot (Eds) At the Household. The Developing Adolescent. Cambridge, M.A. Harvard University Press.

Day-Vines NL, Day-Harrison BO (2005) Culturally congruent strategies for addressing the behavioural needs of urban African American male adolescents. Professional Counseling, 8(3): 236.

Douglas, MA, \& Strauss? (2007) "Discipline by Parents and Child Psychopathology", in Felthous, A.; Sass, H., International Handbook of Psychopathology and the Law., New York: Wiley, pp. $1-2$.

Fowers BJ (2008) From Continence to Virtue: Recovering Goodness, Character Unity, and Character Types for Positive Psychology. Theory \& Psychology, Vol. 18, No.5,629-653.

Keoreng E (2004) Research blames corporal punishment for school dropouts. Mmegi Newsletter. Gaborone 12 November.

Kodilinye, C. (1990). Nigerian Law of Torts, Ibadan: Spectrum Law Publishing.

Maleke L (2003) Head teachers prescribe the stick. Mmegi Newsletter. Gaborone 17 October. Poor citation.

Matsimoto D (2000) Culture and Psychology (2nd Edition), Wadsworth Thomson Learning U.S.A.

Mbiti J (1988) African religion \& philosophy. London: Heinemann. Nakpodia ED (2003) “Principals' Disciplinary powers in Secondary School Administration", Journal of Teachers and Teaching 5(5).

Mclntyre T Silva P (1992) Culturally Diverse Childrearing Practices: Abusive or Just Different? Beyond Behaviour. 4(1):8-12.

Nakpodia ED (2006) Educational Administration: A New Approach, Warri Jonokase Nig. Co.

Nakpodia ED (2007) Education Law, Warri Jonokase Nig. Co

Nakpodia ED (2009) "Perceptions of Principals' Responsibilities in-locoparentis in Nigerian Secondary Schools." International Journal of Educational Sciences. Vol. 1, No. 2 
Nwideeduh SB (2003) "Maintaining Effective Classroom Control and Discipline" in S.B. Nwideeduh, (ed). Focus on Effective Teaching in Schools Portharcourt, Paragraphics.

Oroka O (1994) Discipline: An Educational concept. Delta Journal of Educational Development, 2(1), 97-108.

Ovwata BB (2000) A Modern Sociology of Education. (2nd Ed.) Warri, COEWA Publishers

Papalia DE; Wendkos-Olds S; Duskin-Feldman R (2006) A child World: Infancy through Adolescence (10th ed.), New York: McGraw-Hill.

Peretomode VF (1993). Introduction to Sociology of Education. Owerri, Totan Publishers Ltd.

Rajab, T. (2015). An Applied Model of Teaching Materials to Improve Students' Speaking Skill. Jurnal Ilmiah Peuradeun, 3(1), 103-118.

Reyes AH (2006) Discipline, Achievement, and Race: Is zero tolerance the answer? Rowman \& Littlefield Education.

Saifullah. (2015). The Internalization of Democratic Values into Education and Their Relevance to Islamic Education Development (Synthetic, Analytic, and Eclectic Implementation of John Dewey's Thoughts). Advanced Science Letters, Journal of Computational and Theoretical Nanoscience, 21 (7), pp. 2301-2304, DOI: 10.1166/asl.2015.6257

Salami, S. (2015). Implementing Neuro Linguistic Programming (NLP) in Changing Students' Behavior: Research Done at Islamic Universities in Aceh. Jurnal Ilmiah Peuradeun, 3(2), 235-256.

Yusoff, M. Z. M., \& Hamzah, A. (2015). Direction of Moral Education Teacher To Enrich Character Education. Jurnal Ilmiah Peuradeun, 3(1), 119-132.

ZA, T. (2014). Islamic Studies dalam Pendekatan Multidisipliner (Suatu Kajian Gradual Menuju Paradigma Global). Jurnal Ilmiah Peuradeun, 2(2), 211-234.

Zindi $F$ (1995) An Analysis of the arguments for an against the use of Corporal Punishment in Zimbabwe's secondary schools. Zimbabwe J. Educ. Research... 7?:69-83. 